\title{
SUSTAINABILITY ANALYSIS OF KPBS PANGALENGAN MILK PROCESSING BUSINESS UNIT USING FLOURISHING BUSINESS CANVAS METHOD
}

\author{
Syarah Nurul Amaliah*)1, Mukhamad Najib ${ }^{* *}$, and Siti Jahroh") \\ *) School of Business, IPB University \\ Jl. Pajajaran Bogor 16151 \\ **) Department of Management, Faculty of Economics and Management, IPB University \\ Jl. Agatis, Campus of IPB Darmaga Bogor 16680
}

\begin{abstract}
Koperasi Peternakan Bandung Selatan (KPBS) as one of the milk cooperatives established Milk Treatment 2 (MT2) as a milk processing business unit to increase the bargaining position of distribution and marketing of milk. The purpose of the research conducted is to analysing the sustainability aspects of MT2 on Flourishing Business Canvas (FBC). The sustainability description of MT2 on FBC makes MT2 able to map sustainability problems that occur in the company. Data and information collection techniques in this study are observation, interviews, and literature study. The study found that Value co-creation conducted by MT2 is the production of high quality and affordable milk-derived dairy products, as well as economic welfare for KPBS members. Other funding showed that the value of co-destruction is due to lack of knowledge, and the weakness of MT2 in markets and capital.
\end{abstract}

Keywords: milk, KPBS Pangalengan, sustainable analysis, sustainable business model, flourishing business canvas

\begin{abstract}
Abstrak: Koperasi Peternakan Bandung Selatan (KPBS) sebagai salah satu koperasi susu membentuk Milk Treatment 2 (MT2) sebagai unit bisnis pengolahan susu untuk meningkatkan posisi tawar distribusi dan pemasaran susu. Tujuan dari penelitian yang dilakukan adalah untuk menganalisis aspek keberlanjutan MT2 pada Flourishing Business Canvas (FBC). Deskripsi keberlanjutan MT2 pada FBC membuat MT2 mampu memetakan masalah keberlanjutan yang terjadi di perusahaan. Teknik pengumpulan data dan informasi dalam penelitian ini adalah observasi, wawancara, dan studi literatur. Studi ini menemukan bahwa co-creation Value yang dilakukan oleh MT2 adalah produksi produk susu yang berkualitas tinggi dan terjangkau, serta kesejahteraan ekonomi bagi anggota KPBS. Pendanaan lain menunjukkan bahwa nilai penghancuran bersama adalah karena kurangnya pengetahuan, dan kelemahan MT2 di pasar dan modal.
\end{abstract}

Kata kunci: susu, MT2 KPBS Pangalengan, analisis keberlanjutan, model bisnis berkelanjutan, flourishing business canvas

\footnotetext{
${ }^{1}$ Corresponding author:

Email: syarah.n.amaliah@gmail.com
} 


\section{INTRODUCTION}

Due to the emergence of a shift in people's consumptions patterns to high value foods, national milk demand is increasing. National milk consumption is predicted to reach 1.14 million tons in 2020 (Kementan, 2016), becoming one of the causes of government programs on national milk self-sufficiency by $40 \%$ in 2020 (Aditya, 2016) and 50\% in 2025 (FFI, 2013) cannot be fulfilled. Domestic milk production has not been able to meet all the needs of fresh milk (Farid and Sukesi, 2011). Most domestic demand $( \pm 80 \%)$ is met from imported milk, and the majority of dairy farms are held by small-scale farmers and cooperatives. The high import of milk has resulted in direct losses to dairy farming in Indonesia. The market share of domestic market players needs to be increased so that the opportunity loss that comes from being unemployed or not utilizing the potential of existing resources for the development of dairy agribusiness. The development of the dairy industry in Indonesia can have a positive effect on improving nutrition in the community and the welfare of dairy farmers.

In the process of fulfilling milk demand, small-scale dairy farmers and cooperatives face various challenges in running their businesses. The Milk Processing Industry (MPI) through a cooperative requires various standards on milk purchased from farmers, both from food safety standards (the number of microbes contained in milk), nutritional standards (such as the total fat contained in milk), and standard quantity. In addition, breeders also face various risks in the process of raising dairy cows, such as weather conditions that cause fluctuations in the availability of forage feed, cattle health conditions that result in cow's milk production, concentrate feed prices for cows, and even the risk of death of cows.

Government policy support to protect domestic milk products has been carried out in the form of a Joint Decree of three Ministers, namely the Minister of Cooperatives, the Minister of Agriculture, and the Minister of Industry \& Trade and then strengthened to Presidential Instruction no. 2 of 1985 regulates the marketing and milk purchase ratio by MPI. With this regulation, MPI is obliged to buy milk from farmers with a ratio of 2:1, meaning that if MPI imports two kilograms of milk powder, it is obligatory to buy one kilogram of fresh milk domestically. This obligation is known as BUSEP (bukti serap or absorptive evidence).
In 1998, there was a significant change in the people's dairy farming business. Changes in the country's political situation in the reform era and see milk as a potential commodity in terms of trade in developed countries, causing the government to accept the proposal of the International Monetary Fund Institute (IMF) to issue Presidential Instruction no. 4 of 1998 which abolished the enactment of Presidential Instruction no. 2 of 1985 concerning BUSEP. This condition revokes the obligation of MPI to purchase fresh milk domestically from farmers.

Government support for local farmers is also carried out in Permentan No. 26 of 2017 concerning the supply and distribution of milk. The regulation regulates the obligation of MPI to partner with local farmers to support domestic milk production. The investment value of the MPI partnership with local farmers reaches Rp 751 billion a year after the enactment of the regulation (Deni, 2018), MPI will also receive incentives if it partners with local farmers (Deni, 2018). However, the government also received pressure from the World Trade Organization (WTO) Dispute Settlement Body (DSB) to cancel the regulation because the US objected to the regulation and threatened to eliminate the Generalized System of Preference (GSP) program on Indonesian export commodities, so it is feared that it will cause a decrease in exports of Indonesian products to the US. This made the government re-issue revisions in Permentan Number 30 Year 2018 and Permentan Number 33 Year 2018 which eliminated the partnership as one of the considerations in the issuance of recommendations (Zuraya, 2018). In the absence of support for local farmers and milk collection cooperatives, local dairy commodities will continue to compete with imported milk, whose prices are volatile. If the price of imported milk is low, MPI will import more milk and can result in the threat of the existence of local dairy farmers. Data on milk imports can be seen in Table 1.

Table 1. Composition of imported milk and local milk in Indonesia

\begin{tabular}{ccc}
\hline \multirow{2}{*}{ Year } & \multicolumn{2}{c}{ Percentage of total (\%) } \\
\cline { 2 - 3 } & Imported milk & Local milk \\
\hline 2011 & 76.51 & 23.49 \\
2012 & 77.66 & 22.34 \\
2013 & 82.04 & 17.96 \\
2014 & 81.03 & 18.97 \\
2015 & 81.31 & 18.69 \\
2016 & 80.88 & 19.12 \\
\hline
\end{tabular}

Source: Kementan (2016) 
Koperasi Peternakan Bandung Selatan (KPBS), which is one of the dairy and dairy farmers cooperatives, established a milk processing business unit (namely Milk Treatment 2 or MT2) in an effort to increase bargaining positions in milk distribution and marketing. As one of the dairy cooperatives in Indonesia, Pangalengan KPBS ranks 52 of the 100 largest cooperatives in Indonesia, and ranked second out of the 10 largest production cooperatives in Indonesia in 2014 according to Muchtar (2015). Research on the milk value chain and inclusive business model at KPBS was conducted by Ramadanti et al. (2017).

KPBS still distributes milk from breeders to MPI, including PT Frisian Flag Indonesia (PT FFI), PT Ultra Jaya, and PT Indolakto. Besides MPI, KPBS also distributed a small portion of its milk products to the home industry. The amount of milk distributed to MT2 is still relatively small compared to distribution to MPI, which is $10.80 \%$ (KPBS Annual Report, 2018) of the total KPBS milk production. The processing of milk carried out by MT2 is pasteurized milk of various flavors, drink yogurt of various flavors, mozarella cheese, butter, and cream cheese. MT2 management is carried out autonomously and is planned to be built with a Limited Liability Company (or Perseroan TerbatasPT) system.

As a KPBS business unit, MT2 is committed to using raw milk from KPBS. As a result of this policy, MT2 will find it difficult to compete with MPI when imported milk prices are falling. In addition, MT2 as a cooperative business unit has the characteristics of weak capital and human resources (HR) compared to MPI, putting MT2 in a risky position. Product diversification carried out by MT2 makes the market segmentation for MT2 products wider, but also has another impact, namely the emergence of by products which if not processed will become waste, for example whey from cheese processing. The existence of MT2 as part of a cooperative also intersects with various stakeholders who have an interest in the existence of MT2, such as 4,556 KPBS members who invest part of their capital in MT2 and expect Sisa Hasil Usaha (SHU) to improve welfare. The characteristics of MT2 that are in a unique position and intersect with various dimensions make MT2 need to pay attention to its sustainability aspects. The sustainability dimension which is based on the triple bottom line: profit, people, planet sparked by Elkington (1997) makes the discussion of sustainable business broader. Although the discussion of sustainability in
Small and Medium Enterprises (SMEs) has not been much discussed because the majority of SMEs are more focused on financial benefits, the portrayal of sustainability in SMEs can reduce costs and reduce risk. The number of SME scale business units is greater than the corporate scale, so that the application of sustainability can be broader and bring more positive environmental and social impacts. SMEs also play a greater role in economic equality so that they are closely related to social aspects. Implementation of sustainability in SMEs can make it easier for SMEs to collaborate with larger businesses because there is more pressure for sustainability ${ }^{-}$applications in corporate business supply chains, supported by the OJK Regulation No. 51/POJK.03/2017 regarding the obligation to prepare sustainability reports for public companies in in 2021.

Implementing sustainability in a company can be complex because of its broad context. Research on sustainable business models is a growing research. Research that has been done include Hart and Milstein (2003), Stubbs and Cocklin (2008), Martinuzzi and Krumay (2013), Abdelkafi and Tauscher (2016), Dyllick and Hockerts (2002), Ludeke-freund and Dembek (2017), Yang et al. (2016), Geissdoerfer et al. (2016), Boons et al. (2013), Bocken et al. (2014), and Bocken et al. (2015). The application of sustainable business models in companies is also examined by Hogevold (2011) and Ritala et al. (2018). Flourishing Business Canvas (FBC) developed by Upward and Jones (2016) is one of the tools that can be used to describe sustainability in MT2. FBC was innovated based on the Business Model Canvas (BMC) coined by Osterwalder and Pigneur (2010). Unlike the BMC which consists of nine elements, FBC consists of sixteen elements consisting of economic, social, and environmental aspects. By depicting sustainability on the canvas, determining sustainability strategies can be simplified and simplifying the direction of sustainability policies in the company. The use of FBC as a method in researching sustainable business models is still limited, including those used by Karlsson et al. (2018), Elkington and Upward (2016), and Hoveskog et al. (2017). Based on the formulation of the problem presented, the purpose of the research conducted is to analysing the sustainability aspects of MT2 on FBC. The depiction of sustainability on the canvas is expected to make it easier to map the strategies needed to implement sustainability in MT2. 


\section{METHODS}

This research was conducted in MT2 Pangalengan KPBS, Pangalengan District, Bandung Regency. Data collection activities carried out in July-October 2018. In this study two types of data were used, namely primary and secondary data. Primary data were obtained from several respondents who had roles in MT2 KPBS Pangalengan. For secondary data obtained through annual reports and KPBS Pangalengan documents, internet, books, journals, previous research and other data sources related to this study.

Data and information collection techniques in this study are observation, interviews, and literature study. The observation technique was used to obtain supporting data about the actual conditions in MT2 KPBS Pangalengan. Interview technique is used as the main method in gathering information and data related to the ideas and thoughts of respondents who are interviewed according to the focus of the study. Respondents were chosen because they have authority in the formulation of strategies and policy making in MT2 KPBS Pangalengan. Literature study is conducted with the aim of studying, understanding, and completing data that is not available or incomplete at the location of the object of research. Secondary data were obtained from the internet, literature reviews (books, journals, theses), and the annual KPBS Pangalengan report. The form of data used in analyzing the MT2 KPBS Pangalengan company model is qualitative data.

Interviews were conducted with MT2 management using semi-structured questions. The interview session results in a mapping of the company model that is being carried out by MT2 KPBS Pangalengan in the form of Flourishing Business Canvas (FBC), which consists of 16 components:

Outcomes: (1) Goals: what are the company's goals? What is the organization's definition of economic, social and environmental success?; (2) Benefits: how does the company choose to measure the benefits of the business model in each relevant unit? (economically, socially, and environmentally); (3) Costs: how does the company choose cost measurements in the business model, and in each relevant unit? (economically, socially, and environmentally)
People: (4) Ecosystem Actors: who and what might have an interest in the company's existence? Which ecosystem actors represent the needs of individuals, groups, organizations, or non-humans? From the moment the ecosystem actor engaged with the company, the actor becomes a stakeholder; (5) Needs: which fundamental needs of the ecosystem actor does the company intend to satisfy via its value co-creation, or that it may prevent an ecosystem actor from satisfying via its value co-destruction?; (6) Stakeholders: who are known as company stakeholders? When ecosystem actors become stakeholders, these actors have a large influence on all elements of the business model; (7) Relationship: what relationship must be built, maintained and cultivated with stakeholders through its channel? What is the function of each relationship in value co-creation or value co-destruction that is relevant to each stakeholder?; (8) Channels: what channels are used for communication and developing relationships with stakeholders, allowing for co-creation or codestruction of each value proposition.

Value: (9) Value Co-Creation: what values are created together with each stakeholder, meeting the needs associated with ecosystem actors, from each perspective, now and in the future? Value co-creation is a positive value proposition of the company; (10) Value Co-Destruction: what values are destroyed by each stakeholder, hindering the fulfillment of needs related to ecosystem actors, from each perspective, now and in the future? Value co-destruction is a negative value proposition of the company.

Process: (11) Governance: which stakeholders can make decisions: who is a recognized stakeholder, company goals, proposed values, and all elements of the business model?; (12) Partnerships: which stakeholders are the company's formal partners? For what resources can the partner enable the company to gain preferred access? What activities do partners do for the company?; (13) Resources: What resources (tangible or intangible) do companies need to achieve their goals?; (14) Biophysical Stocks: from which original stock tangible resources are transferred/transformed by the company to achieve its objectives?; (15) Activities: the work of adding value that is organized into processes, which require the design, delivery and maintenance of value co-creation and value co-destruction to achieve the company's goals; (16) Ecosystem services: ecosystem services are 
solar-powered processes that use biophysical stocks to create a flow of benefits for human needs: clean water, fresh air, fertile soil, animal growth, etc. Which flow of benefits is needed, endangered, or enhanced by the company's activities?

The operational framework for this research is explained in Figure 1. The aspects of MT2 sustainability are analyzed and grouped into three aspects, namely economic, social and environmental. After that, aspects of sustainability are described in 16 FBC elements and produce FBC prototypes. The depiction of sustainability at FBC produced recommendations for MT2.

\section{RESULTS}

\section{Pangalengan KPBS Profile}

Pangalengan KPBS was established on April 1, 1969 after a long history of Dutch colonialism. During this period, there were four dairy companies in Pangalengan, namely De Friesche Terp, Almanak, van der Els, and Bigman. Small-scale farmers in Pangalengan began to emerge since Dutch colonialism was replaced by Japanese colonialism. Since then, the presence of cooperatives was urgently needed by small-scale farmers to meet the collective needs of dairy farming activities and to continue marketing fresh milk.
The journey of dairy cooperatives in Indonesia was hit by various problems. Besides the problem of the low ability of cooperative management, the main problem faced by dairy cooperatives is in the marketing of milk to the MPI. Dairy cooperatives have a very weak bargaining position in dealing with MPI, both in determining the amount of milk sales, time of sale and prices obtained.

The problem faced arises because MPI uses imported milk as raw material and does not want to absorb domestic milk. Although drinking milk continues to be campaigned for, the demand for fresh milk produced by cooperatives actually gets a tough competition with the presence of various processed MPI milk products. Farmers who have been successfully directed to increase domestic milk production are disappointed because a lot of milk is damaged and must be discarded. As an example experienced by KPBS Pangalengan between 1969-1979, recorded milk damage at the level of farmers who had to be discharged reached 250,000 liters per year (Syarief, 1997). This happened because in that year KPBS Pangalengan faced severe challenges, including: (a) acceptance by MPI only on weekdays, (b) MPI demanded the milk had been processed by cooling, (c) marketing of milk to direct consumers quite difficult due to the quality of milk is not guaranteed and the existence of counterfeiting milk by retailers, (d) the level of milk damage at the cooperative and farmer level is quite high.

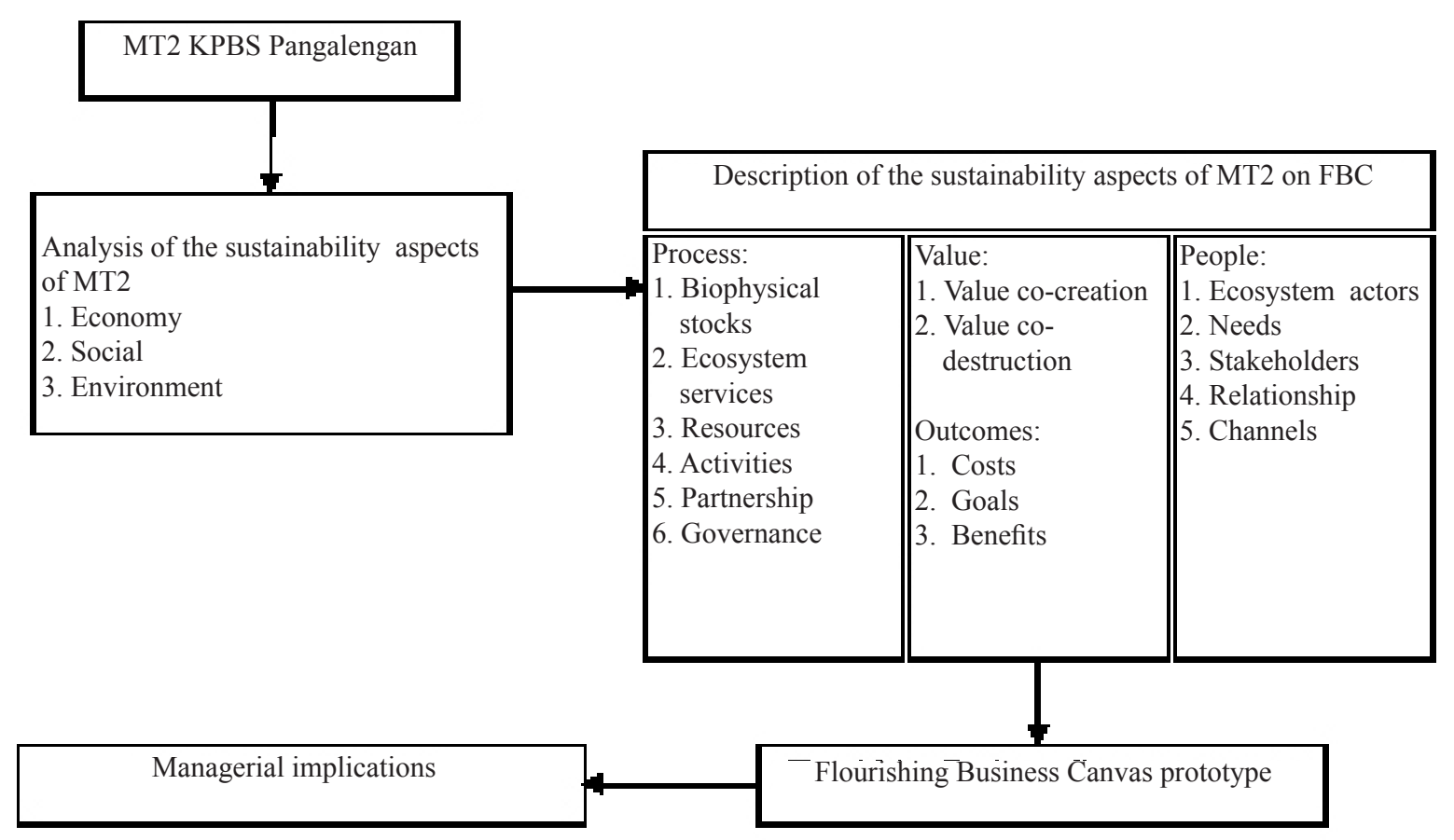

Figure 1. Reseach framework 
To deal with these unfavorable situations and conditions, the Annual Member Meetings (or Rapat Anggota Tahunan-RAT) in 1976 and 1977 decided to establish Milk Treatment (MT). The construction was carried out with a loan capital from PT Ultra Jaya. Based on the RAT decision, KPBS built the MT with payment for 5 years in installments in the form of member shares amounting to Rp 25,- per liter. January 1, 1979 began construction of the MT and was inaugurated on July 16, 1979 by the Deputy Minister of Cooperative Affairs of the Republic of Indonesia. In November 1982, the signing of the transfer of management from PT Ultra Jaya was witnessed by the Minister of Cooperatives and Deputy Governor of West Java Province, then in July 1983 the installments could be repaid.

The benefits with MT operation are: (a) milk production can be absorbed every day even though MPI only receives on weekdays, (b) milk damage at the cooperative level or in farmers can be reduced, (c) increased services and businesses in the form of investment to accelerate welfare members, (d) in 19801983 KPBS Pangalengan could assist in the reception of milk from milk cooperatives in West Java. In 1997, KPBS Pangalengan pioneered marketing to consumers directly in the form of pasteurized milk in cup and pillow packaging under the KPBS Pangalengan brand. In 2013, KPBS Pangalengan decided to diversify more products and established MT2 in collaboration with third parties and had more complete machines for processing. In 2017, MT2 strived to become an autonomous business unit and was established as a Limited Liability Company (PT) KPBS.

\section{Depictions of MT2 Sustainability on Flourishing Business Canvas}

Flourishing Business Canvas (FBC) is grouped into four perspectives (outcomes, people, values, processes) that contain three contexts (economic, social, and environmental). The depiction of MT2 sustainability in FBC is attached in Figure 2. Color differences in the sticky notes box are done to distinguish context, red for economic context, yellow for social context, green for environmental context, and purple if factors in the sticky notes are related in several contexts.

\section{Flourishing Business Canvas v2.0}

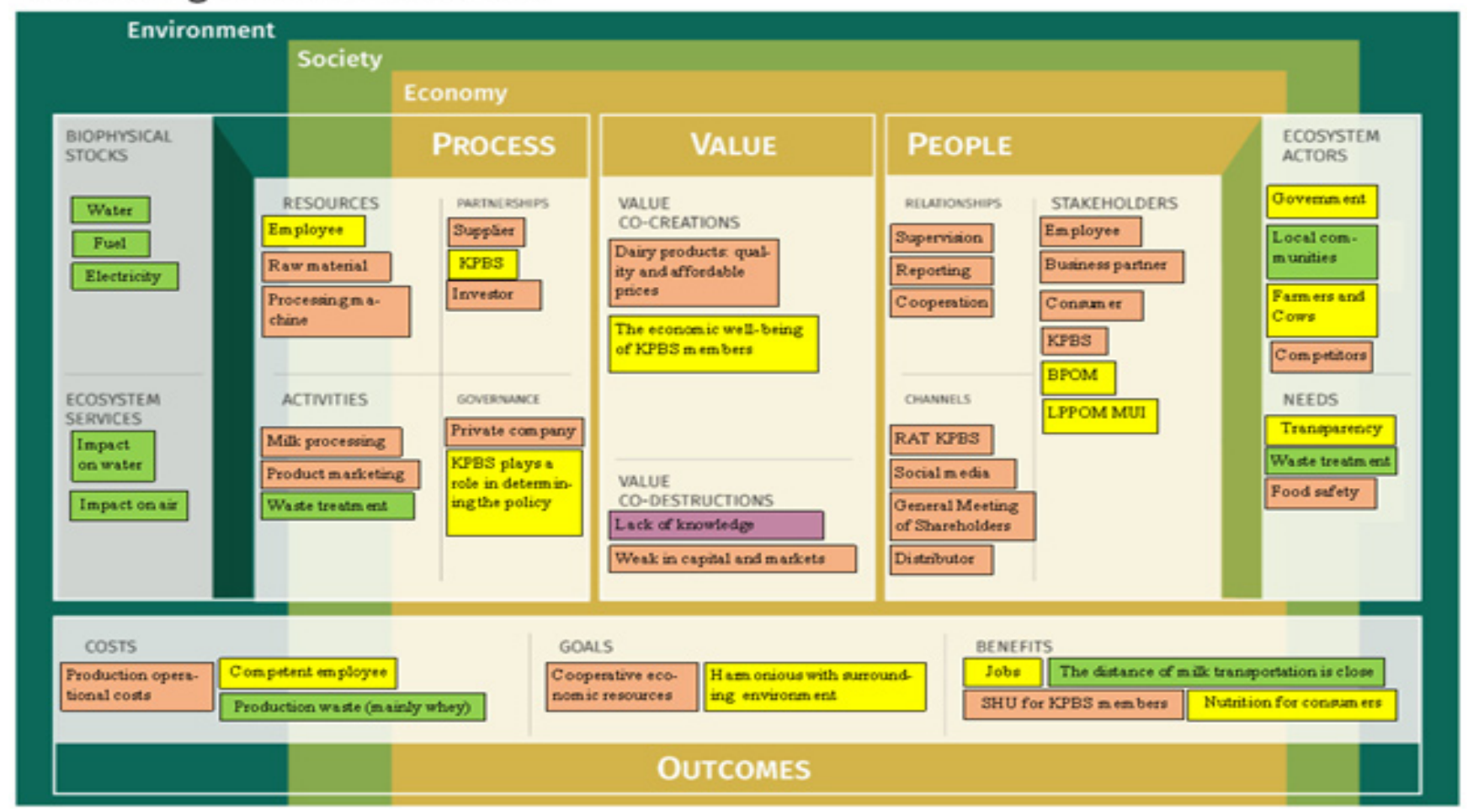

Figure 2. Flourishing Business Canvas of MT2 KPBS Pangalengan 


\section{Outcomes: Goals, Benefits, Costs}

The existence of MT2 as one of the KPBS Pangalengan business units functions as a cooperative economic resource. In its operations, MT2 and KPBS Pangalengan want harmony with the surrounding conditions, including social and environmental. The existence of MT2 also provides economic, social and environmental benefits. MT2 which is located in a rural area opens up employment opportunities for the surrounding community. The MT2 location which is closer to the raw material makes the transportation distance traveled by fresh milk closer, and reduces the transportation costs charged to KPBS. MT2 as a business unit can also improve the welfare of KPBS members with the Sisa Hasil Usaha (SHU) from MT2 operational activities. MT2 products based on milk can also provide improved nutrition for consumers.

The costs required by MT2 to keep its operations running are production operational costs, such as procurement of raw materials, supply of equipment, transportation costs. In addition, MT2 also has social costs, namely competent human resources. Employees who work at MT2 generally come from the surrounding community, some of whom have barriers to working elsewhere, such as the high qualifications required or the high cost of living in a new place. Consequently MT2 must conduct training for its employees so that the quality of MT2 HR can compete with MPI. Environmental costs that need to be considered by MT2 are the processing of production waste, especially the processing of whey which is a by-product of processing cheese. The limitations of MT2 in whey processing makes MT2 loss its opportunity to gain another product from whey.

\section{People: Ecosystem actors, Needs, Stakeholders, Relationships, Channels}

In this perspective, it is explained about the parties involved in business, both those involved to create value co-creation and those who are threatened because of the value of co-destruction. Ecosystem actors are all lives involved in the business value chain, non-humans elements are also involved (Elkington and Upward, 2016). Ecosystem actors involved in the MT2 business value chain include the government, both from the Ministry of Cooperatives and SMEs, Ministry of Industry, Ministry of Health, BPOM, or LPPOM MUI, surrounding communities, breeders and cattle, and competitors. The form of government involvement is carried out by drafting regulations that must be obeyed by the business. The surrounding community is affected by the existence of MT2 due to its operational activities, such as transportation around the business location or waste from the production. Breeders and cows that are connected through KPBS have certainty in distributing fresh milk produced. Competitors are affected by the presence of MT2 due to the presence of new products on the market.

The needs that are required by each ecosystem actor vary. These needs are grouped into transparency for the government and stakeholders that are directly related to MT2 activities, waste management for the environment, and food safety for consumers. Stakeholders who have a direct role in MT2 include employees, business partners, consumers, KPBS, BPOM and LPPOM MUI. Employees, business partners and consumers play a role in MT2 operational activities, especially the supply chain of MT2 production activities. KPBS has a role in determining policy in MT2, because one of MT2's functions is as a KPBS business unit. BPOM and LPPOM MUI play a role in the MT2 product distribution authority, especially regarding food safety and product halal status. The relationship that exists between MT2 and its stakeholders is supervision, reporting, and collaboration. Channels used by MT2 include social media and distributors to reach consumers, the General Meeting of Shareholders (GMS) and the Annual Members Meeting (RAT) of KPBS to determine policies with the various stakeholders involved.

\section{Value: Value co-creations, Value co-destructions}

This perspective explains the value that is created and destroyed by the MT2 business process. Value cocreation is a positive value proposition of business activities, while value co-destruction is a negative value proposition arising from business activities. In general, companies will only discuss value co-creation and hide value co-destruction for fear of having an impact on the company's image. In fact, the value of codestruction can be seen as a threat that will arise if not addressed. Value co-destruction can also arise if there is an imbalance in one context, for example companies only pay attention to financial benefits without regard to social and environmental conditions in the company. 
Value co-creation is formed from MT2 business activities, namely quality milk products at affordable prices, and economic welfare of KPBS members with the addition of SHU from MT2 business activities. Value co-destruction is formed due to the lack of knowledge that can have an impact on competitive advantage and production efficiency. MT2 as a cooperative business unit is also relatively weak in capital and markets when compared to MPI.

\section{Process: Governance, Partnerships, Resources, Biophysical stocks, Activities, Ecosystem services}

This perspective explains the processes carried out in MT2 business activities. The governance carried out by MT2 is based on various decision makers. MT2 in collaboration with third parties makes the shareholders involved in MT2 not only KPBS. Decision making is done at RUPS and RAT KPBS. MT2 belongs to a private company because the shareholders involved only consist of a few parties, members of KPBS who invest in MT2 are represented by KPBS in their ownership. KPBS as the parent of the MT2 business also plays an important role in making policy in MT2, and one of the KPBS managers also serves as a director at MT2.

Partnerships are carried out when companies need to formally collaborate with stakeholders to ensure certainty of the availability of resources. MT2 partnerships are conducted with suppliers, KPBS, and investors. Resources used by MT2 in its operational activities are raw materials, processing machinery, and employees as human resources. Biophysical stocks involved in MT2 operational activities are water, fuel, and electricity. Activities undertaken by MT2 to create value are milk processing, product marketing, and waste treatment. Ecosystem services that are likely to be affected by MT2 business activities are water and air in the MT2 operational environment.

\section{Managerial Implication}

The development of sustainable business models for small and medium scale businesses has not been applied much. The majority of SMEs focus more on financial benefits. Aspects that include sustainability are also broad, requiring a deeper understanding of the overall economic, social and environmental fields. Flourishing Business Canvas (FBC) can be used as a tool to understand sustainability in the company as a whole. The application of sustainability in companies can improve efficiency and economic value, make SMEs driven to the application of sustainability in companies.

The description of sustainability in FBC is only done qualitatively. Nevertheless, the description of sustainability can help companies to see sustainability as a whole. FBC is a new tool for describing sustainability, and because of its broad context and many elements make FBC more complex and requires deeper understanding. By knowing the picture of sustainability holistically on FBC, MT2 can determine its focus on which aspects of sustainability need to be improved.

FBC is still in the development and trial phase. Some researchers feel that FBC is too complex (Broeck 2017, Karlsson et al. 2018). To overcome this complexity, FBC users need a better understanding of the core of sustainability and its practical use. Along with the many uses of FBC, there will be more examples of using FBC and make it easier for users to use $\mathrm{FBC}$ applications in the company. FBC elements have more extensive and broader context makes FBC can be developed according to company needs. The depiction of elements in FBC is not limited to what needs to be improved from the company, but also threats that can arise in the long run. For example, social and environmental sustainability in companies where the majority of companies have not integrated the context into the company's strategy.

\section{CONCLUSIONS AND RECOMMENDATIONS}

\section{Conclusions}

Flourishing Business Canvas is a prototype of a sustainable business model that covers three contexts (economic, social, and environmental) and is divided into four perspectives (outcomes, process, value, people). With elements in FBC consisting of sixteen elements, the use of $\mathrm{FBC}$ becomes more complicated compared to BMC. The goals to be achieved by MT2 are harmony with the surrounding environment, and make MT2 as a cooperative economic resource. Benefits generated by MT2 include the opening of employment opportunities, SHU for KPBS members, the distance of transportation of raw milk closer, and nutrition for consumers. Costs to be borne by MT2 are operational costs of production, competent human resources, and treatment of production waste. 
Value co-creation conducted by MT2 is the production of high quality and affordable milk-derived dairy products, as well as economic welfare for KPBS members. The value of co-destruction that occurs in MT2 is due to lack of knowledge, and the weakness of MT2 in markets and capital. Stakeholders involved in MT operational activities include employees, business partners, consumers, KPBS, BPOM, and LPPOM MUI. Ecosystem actors involved include the government, surrounding communities, breeders and cattle, and competitors. Needs needed by ecosystem actors and stakeholders are transparency, waste management, and food security. Relationships developed by MT2 with ecosystem actors and stakeholders in the form of supervision, reporting, and collaboration. The channels used by MT2 to reach stakeholders involved with MT2 are RAT KPBS, social media, GMS, and distributors. Resources needed by MT2 to operate are employees, raw materials, and processing machines. Biophysical stocks used by MT2 are water, fuel and electricity. Ecosystem services that may be affected by MT2 activities are water and air in the environment. Activities undertaken by MT2 are milk processing, product marketing, and waste treatment. MT2 has partnerships with suppliers, KPBS, and investors. Governance that plays a role in MT2 is KPBS, and the company system that is held is the private company.

\section{Recommendations}

Implementation of sustainability in SMEs and business units related to cooperatives is interesting to study, because the characteristics of SMEs and cooperatives are different from large scale businesses. The majority of SMEs that focus on financial benefits, without paying too much attention to social and environmental benefits, do not make the sustainability strategy in SMEs unworkable. With the presence of FBC as a tool for depicting sustainability, implementing sustainability in other companies that are more critical in their social and environmental contexts is expected to be easier to do. The description of MT2 sustainability in FBC is qualitative. Further research can be carried out quantitative research of the elements described in FBC. In addition, expanding the sustainability study in the KPBS value chain is also interesting to do. There are several business model tools that can be used to describe sustainability in addition to $\mathrm{FBC}$, including the Triple Layered Business Model Canvas (TLBMC), which was initiated by Joyce and Paquin (2016).

\section{REFERENCES}

[FFI] Frisian Flag Indonesia. Commitment to develop dairy village [Internet]. Frisian Flag. FDOV@ en.https://www.frisianflag.com/en/2013/11/ frisian-flag-indonesia-ptpn-viii-kpsbu-lembangsign-commitment-develop-dairy-villageachieving-sustainable-dairy-farming-indonesia/. [27 Jun 2018].

Abdelkafi N, Täuscher K. 2016. Business models for sustainability from a system dynamics perspective.Organization \&Environment (29)7496. https://doi.org/10.1177/1086026615592930.

Aditya. Terancam tak tercapai, target swasembada susu $40 \%$ pada 2020 . http://agro.kemenperin. go.id/4445-Terancam-Tak-Tercapai.-TargetSwasembada-Susu-40\%25-pada-2020. [27 Jun 2018].

Bocken NMP, Rana P, Short SW. 2015. Value mapping for sustainable business thinking. Journal of Industrial and Production Engineering 32:1, 6781. https://doi.org/10.1080/21681015.2014.100 0399.

Bocken NMP, Short SW, Rana P, Evans S. 2014. A literature and practice review to develop sustainable business model archetypes. Journal of Cleaner Production 65 (2018) 42-56. https:// doi.org/10.1016/j.jclepro.2013.11.039.

Boons F, Montalvo C, Quist J, Wagner M. 2013. Sustainable innovation, business models and economic performance: an overview. Journal of Cleaner Production 45 (2013) 1-8. doi: 10.1016/j.jclepro.2012.08.013.

Broeck FV. 2017. The flourishing business canvas: the new tool for business modelling, a multiple case study in the fashion industry. [thesis] University of Boras: The Swedish School of Textiles.

Deni S. 2018. Bermitra dengan Peternak Lokal, Industri Bakal dapat Insentif Bea Masuk. https://www. liputan6.com/bisnis/read/3587835/bermitradengan-peternak-lokal-industri-bakal-dapatinsentif-bea-masuk. [20 Dec 2018].

Deni S. 2018. Kemitraan Industri dan Peternak Lokal Catatkan Nilai Investasi Rp 751 Miliar. https:// www.liputan6.com/bisnis/read/3592726/ kemitraan-industri-dan-peternak-lokal-catatkannilai-investasi-rp-751-miliar [20 Dec 2018].

Dyllick T, Hockerts K. 2002. Beyond the business case for corporate sustainability. Business Strategy and the Environment (11) 130-141. https://doi. org/10.1002/bse. 323 
Elkington J. 1997. Cannibals With Forks: The Triple Bottom Line of 21st Century Business. Oxford: Capstone. https://doi.org/10.1002/ tqem.3310080106.

Elkington R, Upward A. 2016. Leadership as enabling fuction for flourishing by design. Journal of Global Responsibility 7(1): 126-144. https://doi. org/10.1108/JGR-01-2016-0002.

Farid M, Sukesi H. 2011. Pengembangan susu segar dalam negeri untuk pemenuhan kebutuhan susu nasional. Buletin Ilmiah Litbang Perdagangan 5(2): 196-221.

Geissdoerfer M, Bocken NMP, Hultink EJ. Design thinking to enhance the sustainable business modelling process, a workshop based on a value mapping process. Journal of Cleaner Production 135:1218-1232.https://doi.org/10.1016/j. jclepro.2016.07.020.

Hart SL, Milstein MB. 2003. Creating sustainable value. Academy of Management Executive 17: 56-57. https://doi.org/10.5465/ame.2003.10025194.

Hogevold NM. 2011. A corporate effort towards a sustainable business model, a case study from the Norwegian furniture industry. European Business Review 23(4): 392-400. https://doi. org/10.1108/09555341111145771

Hoveskog M, Halila F, Mattsson M, UpwardA, Karlsson N. 2017. Education for sustainable development: business modelling for flourishing. Journal of Cleaner Production 172: 4383-4396 https://doi. org/10.1016/j.clepro.2017.04.112.

Joyce A, Paquin RL. 2016. The triple layered business model canvas: A tool to design more sustainable business models. Journal of Cleaner Production (2016): 1-13. http://dx.doi.org/10.1016/j. jclepro.2016.06.067.

Karlsson N, Hoveskog M, Halila F, Mattsson M. 2018. Early phases of the business model innovation process for sustainability: Addressing the status quo of a Swedish biogas-producing farm cooperative. Journal of Cleaner Production 172: 2759-2722. https://doi.org/10.1016/j. jclepro.2017.11.136.

[Kementan] Kementerian Pertanian. 2016. Outlook Komoditas Pertanian. Jakarta: Pusat Data dan Sistem Informasi Pertanian, Sekretariat Jenderal Kementerian Pertanian.

Ludeke-Freund F, Dembek K. 2017. Research and practice on sustainable business models: emerging field or passing fancy?. Journal of Cleaner Production 168:1668-1678 https://doi. org/10.1016/j.jclepro.2017.08.093.

Martinuzzi A, Krumay B. 2013. The good, the bad, and the successful - how corporate social responsibility leads to competitive advantage and organizational transformation. Journal of Change Management 13: 424-443. https://doi.o $\mathrm{rg} / 10.1080 / 14697017.2013 .851953$.

Muchtar I. 2015. Indonesia's Largest Cooperatives. Jakarta: PT Berkah Dua Visi.

Osterwalder A, Pigneur Y. 2010. Business Model Generation. New Jersey (Kanada): John Wiley $\&$ Sons, Inc.

Ramadanti A, Daryanto A, Sukardi. 2017. The dairy value chain, inclusive business model, and inclusiveness improvement of Southern Bandung Dairy Cooperative (KPBS) Pangalengan. Jurnal Manajemen \& Agribisnis 14(3): 240-249. https:// doi.org/10.17358/jma.14.3.240.

Ritala P, Huotari P, Bocken N, Albareda L, Puumalainen K. 2018. Sustainable business model adoption among S\&P 500 firms: a longitudinal content analysis study. Journal of Cleaner Production 170: 216-226. https://doi.org/10.1016/j. jclepro.2017.09.159.

Stubbs W, Cocklin C. 2008. Conceptualizing a "sustainability business model". Organization \& Environment 21: 103-127. https://doi. org/10.1177/1086026608318042.

Syarief A. 1997. Membangun Usaha Koperasi Persusuan Mandiri: Pengalaman, Pemikiran dan Perjuangan Drh. H. Daman Daniwidjaja. Bandung: KPBS Pangalengan.

Upward A, Jones P. 2016. An ontology for strongly sustainable business models: defining an enterprise framework compatible with natural and social science. Organization \& Environment 29 (Special Issue): 97-123. https://doi. org/10.1177/1086026615592933.

Yang M, Evans S, Vladimirova D, Rana P. 2016. Value uncaptured perspective for sustainable business model innovation. Journal of Cleaner Production 140(3)L : 1794-1804. https://doi.org/10.1016/j. jclepro.2016.07.102.

Zuraya N. 2018. Dirjen: Revisi Permentan Susu Dampak Keputusan WTO. https://republika.co.id/berita/ ekonomi/pertanian/18/09/03/pdj2av383-dirjenrevisi-permentan-susu-dampak-keputusan-wto [20 Dec 2018]. 